\title{
Smart Specialization as a Tool to Foster Innovation in Emerging Economies: Lessons from Brazil
}

\author{
Anna Bosch \\ MA (International Affairs) ${ }^{\mathrm{a}}$, annabosch@gwu.edu
}

\section{Nicholas Vonortas}

Professor, Institute for International Science and Technology Policy, and Department of Economics ; São Paulo Excellence Chair in Technology and Innovation Policy ${ }^{\text {b }}$ Leading Research Fellow: Institute for Statistical Studies and Economics of Knowledge c, vonortas@gwu.edu

\author{
${ }^{a}$ George Washington University, 1957 E Street, N.W., Suite 403, Washington, D.C., 20054 USA \\ b Universidade Estadual de Campinas (UNICAMP), Cidade Universitária Zeferino Vaz - Barão Geraldo, Campinas - \\ SP, 13083-970, Brazil \\ ${ }^{c}$ National Research University Higher School of Economics, 20, Myasnitskaya str., Moscow 101000, \\ Russian Federation
}

\begin{abstract}
$\mathrm{T}$ his paper is about the policy concept of smart specialization (RIS3) and its potential for application in emerging economies. This is an important issue as emerging economies continue to struggle against the forces of globalization and targeted investments through RIS3 strategies may help them boost their (regional) innovation economies. Thus far, RIS3 has mostly been implemented by industrialized EU economies. Due to the structural differences, success in emerging

economies may require more extensive groundwork prior to the implementation of an RIS3 strategy. This is specifically noted in the Brazilian example: smart specialization requires careful planning, the country needs to address some of its general issues with lagging innovation before it can focus on successfully implementing an RIS3 strategy. We believe that such an approach would be appropriate for other countries at similar stages of economic development.
\end{abstract}

Keywords: smart specialization; science, technology and innovation (STI) policy; regional innovation system; regional development; policy learning; European Union; Brazil
Citation: Bosch A., Vonortas N. (2019) Smart Specialization as a Tool to Foster Innovation in Emerging Economies: Lessons from Brazil. Foresight and STI Governance, vol. 13, no 1, pp. 32-47. DOI: 10.17323/25002597.2019.1.32.47 
$\mathrm{T}$ oday's global economy relies on innovation to solve long-existing and new problems. This is why innovation and regional development are a concern for many countries around the world, developing and industrialized alike. To this end, the placebased approach of smart specialization has become a prominent strategy to promote innovation in lagging regions. As the European Union has pioneered the approach of smart specialization (RIS3) with some success, it has been able to gain a great deal of practical experience in implementing RIS3 strategies that can teach emerging economies important lessons about the conditions required for successful strategies.

On the basis of these experiences, this paper will be investigating the ability of smart specialization to promote innovation in emerging economies by examining the current environment in Brazil and extrapolating lessons for other developing countries. There is an extensive body of literature on smart specialization as a policy concept, its theoretical framework, and conditions for success [Boschma, 2013, 2016; Foray, 2015, 2016, 2017; McCann, Ortega-Argilés, 2013, 2016b; Radosevic, 2017]. With respect to innovation, the case of Brazil is an interesting one: it has many essential assets to be a leading innovator but struggles to turn its advantages into world-class initiatives [Ingold et al., 2015]. The question as to why Brazil has not been able to catch up remains a puzzle with much writing on the topic and many different answers, ranging from lack of collaboration in businesses, huge bureaucratic bodies, too little investment in the education of the public - the list goes on (see e.g., [Baer, 2012; Cavalcante, Uderman, 2012; Esteves, Feldmann, 2016; Maragna, 2016; Mazzucato, Caetano, 2016; Negri, 2018; Pinto, 2018]). Within an EU-Brazil partnership on smart specialization, the potential for smart specialization in Brazil has already been identified and pilot projects are being implemented in some regions [Maragna, 2016; Pinto, 2018]. By assessing the current state of existing smart specialization initiatives, this research purports to identify whether it makes sense to expand Brazil's efforts to implement a smart specialization strategy, or if other issues need to be addressed with more urgency before a smart specialization approach can be successful. We find that, due to structurally specific circumstances, success of RIS3 in Brazil may require more extensive groundwork prior to the implementation of a smart specialization strategy.

\section{The Concept of Smart Specialization}

Around 2009, the European Union's (EU) 'Knowledge for Growth' Expert Group developed the notion of 'smart specialization' while discussing foreign $\mathrm{R} \& \mathrm{D}$ investments in European regions and how they could become more attractive to a global firm's investments [European Commission, n.d.; Foray, 2015]. In essence, the idea of smart specialization is that particularly less advanced and emerging regions must build capabilities within specific fields, sub-systems, and technologies to establish themselves in a position of competitive advantage in market niches [European Commission, 2018c; Foray, 2017]. Rather than producing a technological 'monoculture' or creating inflexible development path dependencies, the goal of smart specialization is to diversify the structure of the regional economy by generating new specialties and options for growth within that region [Landabaso, Foray, 2014; Landabaso et al., 2014]. RIS3 is an ambitious and innovative approach aimed at boosting jobs and regional growth through a partnership-based and bottom-up approach that brings together local authorities, academia and business spheres as well as society [European Commission, n.d.]. The following section will explore the concept of smart specialization and its goals in more detail before moving on to identifying factors that can help a smartspecialization strategy to succeed.

\section{The Conceptual Model of Smart Specialization}

The ability of an economic system, such as a geographic region, to discover new opportunities and to concentrate resources and competences in these newly found domains is what generates new 'specialties' [Foray, 2015]. Smart specialization, therefore, describes this capacity to initiate structural changes by diversifying, transitioning, modernizing, or founding new industries and services [Radosevic, 2017]. Through the local concentration of competences and resources in a number of new domains, productive structures can be transformed [Boschma, 2016; OECD, 2013]. Smart specialization is embedded in these productive structures and local resources that require new technologies, competences, and resources to be transformed [Asheim, 2018; Foray, 2015]. When an innovative project complements existing productive assets, a new activity emerges from smart specialization. At the center of this process are businesses, as they are in an ideal position to test new ideas and explore the viability of structural changes in cooperation with research institutions or other social organizations [Foray, 2015; Oliveira et al., 2014].

Based on the classical economic theories of growth, such as Adam Smith's concept on the division of labor and trade specialization, smart specialization is part of a family of more recent strands of economic approaches [OECD, 2013]. Particularly the concepts of increasing returns to knowledge, the role of knowledge spillovers, and market barriers that prevent shifts in regional advantages drawn from the economics of agglomeration and evolutionary economics constitute the essential elements of the smart specialization theory [European University Association [EUA], 2018; Radosevic, 2017]. Moreover, smart specialization also draws on industrial development theories, flexible specialization, and neoclassical spatial economics [Crespo et al., 2017; Radosevic, 2017]. Evidently, RIS3 is a regionally-focused economic framework that aims at demonstrating how public policy frameworks, in particular those that encourage R\&D and innovation investments, can generate scientific, technological, and economic specialization and subsequently increase competitiveness, productivity, and ultimately economic growth [McCann, Ortega-Argilés, 2013].

Specifically, the basic goals of smart specialization, as defined by [Foray, Goenaga, 2013], are: 
- Facilitating the development and growth of new activities with the potential for innovation and spillover

- Generating new options for production and thus diversifying regional economic systems

- Within a diversified system, establishing critical networks and clusters

Smart specialization as a development dynamic can emerge spontaneously (although this is rare) [Boschma, 2013]. A smart specialization strategy on the other hand involves setting up a process in which targeted governmental intervention can facilitate and support discovery, experimentation, structural changes to existing production processes, and the potential development of new specialties when it cannot occur spontaneously [Landabaso et al., 2014]. The following elements are crucial to the policy of smart specialization:

- Entrepreneurial discovery represents the primary source of information with respect to the exploration of new opportunities and the transformational activities that should be prioritized. The private sector runs this process while governments are responsible for providing the conditions in which this exploration can successfully happen and improve coordination between actors [OECD, 2013; Boschma, 2016; Foray, 2015; Gheorghiu et al., 2017].

- It does not matter in which sector or by which individual projects specializations are discovered. Activities are the primary criteria for setting priorities for investments. Generally, future priorities are those activities in which existing productive assets are complemented by new innovations [OECD, 2013, JRC EC, n.d.; Landabaso, Foray, 2014].

- Each sector and each territory have the opportunity to be included if it can shape promising structural transformation projects. RIS3 strategy blurs the lines between 'modern' and traditional sectors, since it is designed precisely to modernize traditional segments [Foray, 2015; Gheorghiu et al., 2017; Landabaso et al., 2014; Landabaso, Foray, 2014].

- Smart specialization strategy is progressive by definition. It continuously pursues new activities and new opportunities for transformation [Foray, 2015; McCann, Ortega-Argilés, 2016a; Radosevic, 2017].

- Rather than targeting pre-determined specialization paths, it is a strategy that is aware of the possibility of unexpected discoveries along the way, which can lead to specialized diversification [Asheim et al., 2017; Balland et al., 2018; Crespo et al., 2017]

- Smart specialization emphasizes the importance of evidence-based monitoring and evaluation to continuously improve policy design [OECD, 2013]. To this end, benchmarks and criteria for success and failure are needed. Policymaking therefore has to be flexible enough to terminate or reallocate public resources when measurable goals are not met [Kotnik, Petrin, 2017; Kuznetsov, Sabel, 2017].

To summarize, a smart specialization strategy is a growth-focused regionally-oriented policy framework that aims at improving the coordination and allocation of public funds toward innovation and R\&D-related investments to stimulate competitiveness and productivity by promoting entrepreneurial activities [OECD, 2013]. Through a bottom-up (entrepreneurial discovery), transparent (monitoring and evaluation), and flexible approach, modern industrial and innovation policies are combined to favor existing experimentation and new activities [Boschma, 2013]. Overall, a smart specialization policy highlights the principle of prioritization to favor certain technologies, populations of firms, and fields (non-neutral) and defines a strategy to determine the advantageous areas for innovation policy interventions [Foray, 2015]. Once identified, activities with the potential to transform existing economic structures through innovation should be promoted by concentrating resources on those activities [Radosevic, 2017].

\section{Smart Specialization in the EU as an Implementation Example}

Although initially an academic idea, smart specialization represented a timely political instrument after the global financial crisis and the euro-zone crisis. Consequently, EU policymakers have embraced the concept of smart specialization rapidly and it now represents the cornerstone of the Europe 2020 strategy [Boschma, 2016]. With its Europe 2020 strategy, the EU wants to leverage existing strengths as well as discover new opportunities and thereby generate new ways for regions to gain competitive advantages [European Commission, n.d.]. For example, to receive funding from the European Structural and Investment Fund (ESIF) in support of the Europe 2020 agenda for jobs and growth, regions now must have a smart specialization strategy [European Commission, 2018b].

The European enthusiasm for smart specialization came from the realization that a top-down, one-sizefits-all approach does not work for the regions of the EU that have very different institutional and economic structures [McCann, Ortega-Argilés, 2016a], which we will see later is true for Brazil as well. In Europe, smart specialization is seen as a way to shape the future development of regions more effectively and help regions grow through a decentralized and more individualized approach [Asheim et al., 2017, McCann, Ortega-Argilés, 2016b]. To this end, the European Commission established the 'Smart Specialization Platform' in 2011, to facilitate learning, data gathering and analysis, and offer networking opportunities for more than 170 EU regions and 18 national governments [European Commission, 2018b]. The platform also advises region$\mathrm{al}$ and national government bodies on how they can develop and implement their own smart specialization strategies [European Commission, n.d.]. Additionally, it encourages regions to join various activities including peer-review sessions and the sharing of experiences and best practices between policy makers [EUA, 2018]. The basis of EU smart specialization strategies is interaction and collaboration between stakeholders in the process of defining the competitive strengths of each region and pursuing synergies within the broader international environment [JRC EC, n.d.]. 
Table 1. Cases of Successful Targeted Support for Local Competitive Assets

\begin{tabular}{|l|l|}
\hline \multicolumn{1}{|c|}{ Country } & \multicolumn{1}{c|}{ Case } \\
\hline France & Environmental engineering and biopharmaceuticals in the Val de Loire \\
\hline Finland & Sustainable smart city developments in Helsinki, Espoo, Tampere, Vantaa, Oulu, and Turku \\
\hline Spain & Smarter and more efficient production of a local distinctive cheese in the rural Extremadura region \\
\hline Romania & Reconversion of collapsing industrial areas into digital development and business support centers \\
\hline Poland & Improvement of links between education and industry in 'aviation valley' \\
\hline \multicolumn{2}{|l}{ Source: [European Commission, 2018b, 2018c]. } \\
\hline
\end{tabular}

Although the EU has attempted to operationalize the principles of smart specialization into concrete elements for regional innovation strategies, the implementation of smart specialization strategies has been criticized as a 'perfect example of policy running ahead of theory' [Foray et al., 2011] and for lacking an 'evidence base' [Foray et al., 2018]. Regardless, the EU has moved rapidly to implement smart specialization: over $€ 67$ billion have been made available since 2011 to support over 120 smart specialization strategies developed by regions in member states [European Commission, 2018a; European Commission, n.d.]. The European Commission (EC) expects these strategies to contribute 15,000 new products to the market, generate 140,000 new start-ups, and 350,000 new jobs by 2020 [European Commission, n.d.]. Successful examples are listed in Table 1.

\section{Identifying Factors for Success}

From a theoretical point of view, smart specialization has been widely accepted as a useful concept. However, there are a multitude of issues with the implementation of smart specialization and achieving these stated goals [Kroll, 2014; Landabaso et al., 2014; McCann, OrtegaArgilés, 2016a]. Practical questions for policymakers range from priority setting to decision making about which activities to support and where to intervene. To date, the literature suggests that regions should capitalize on those activities that are characterized by high technological relatedness and areas with the potential to increase the complexity of their knowledge base and production activities [Balland et al., 2018; Kotnik, Petrin, 2017]. Another important concern is how regional policymakers can involve local stakeholders effectively without risking that the smart specialization process is captured by specific interest groups or lobbies [Boschma, 2016; McCann, OrtegaArgilés, 2016b]. Evidently, much has been written on this topic specifically and covering this debate would require a separate study.

Factors that define the success of smart specialization in achieving the aforementioned goals are summarized in Table 2.

It is important to keep in mind, however, that smart specialization strategies represent a framework within which the policy agenda may operate differently in each regional case - the success of such strategies is highly dependent upon the extent to which it is tailored to the structural environment of the country in question. Challenges for different regions can differ due to regionally specific economic conditions or governance issues [Landabaso et al., 2014]. The factors for success identified here should therefore be seen as a floor rather than a ceiling.

\section{Why Emerging Economies Should Care about Smart Specialization}

The goals of smart specialization are desirable to achieve for any economy looking to increase its economic growth. Developing countries often struggle with achieving sustainable development and establishing an environment in which businesses and innovation can thrive in the long-term [Asheim, 2018]. The smart specialization concept requires countries and their regions to conduct systematic and constructive comparisons in order to a) identify their own competitive advantages and b) understand the international and national context of industries and sectors to learn from others and/or collaborate with them [McCann, OrtegaArgilés, 2016b]. The targeted investments required by an RIS3 approach can harness globalization in ways that favor innovation, encourage private investments, and help countries climb up the value chain [Barroeta et al., 2017]. Moreover, the way the concept of smart specialization is designed favors decentralized innovation policies which can be advantageous for countries that struggle with centralized STI governance due to institutional issues [European Commission, 2017].

Within the framework of the project for S3 in lagging regions, the EU has strategically provided support to southern and eastern European regions that were struggling to implement effective S3 approaches by taking S3 as the starting point to improve their understanding of sluggish growth in those regions and to identify the links to macroeconomic conditions [JRC EC, n.d.]. In a case study of the implications of the economic crisis in Greece on S3 implementation, for example, Marques and Morgan [Marques, Morgan, 2018] emphasized that capability building was just as (if not more) important as institutional capacity. Their work suggests that in such situations S3 can go beyond the regionally specific innovation focus and actually support larger (national) agendas [Marques, Morgan, 2018; Veldhuizen et al., 2018].

Despite these limitations, emerging economies have a lot to gain from observing what the EU is doing on smart specialization: they can sit back and watch the EU determine best practices and spend money on strategy design which they may be able to implement later on. Such implementation can be easier for them 


\section{Table 2. Summary of Factors that Define the Success of Smart Specialization}

\begin{tabular}{|c|c|}
\hline Source & Description \\
\hline $\begin{array}{l}\text { [Foray, Goenaga, } \\
\text { 2013] }\end{array}$ & Good institutions and strong policy capabilities at the regional level \\
\hline [OECD 2013] & $\begin{array}{l}\text { Effective and active coordination of policy interventions, such as an efficient mix and alignment of policy } \\
\text { instruments in order to achieve strategic coordination between national governments and regional } \\
\text { implementation, focusing on the long-term vision }\end{array}$ \\
\hline $\begin{array}{l}\text { [Balland et al., 2018; } \\
\text { Boschma, 2016; } \\
\text { Crespo et al., 2017; } \\
\text { Landabaso et al., } \\
\text { 2014] }\end{array}$ & $\begin{array}{l}\text { The concept of technological relatedness means that the higher the number of technologically related industries } \\
\text { present in a region, the more opportunities are available to develop new industries out of the existing ones and } \\
\text { use and recombine available capabilities and resources in new activities. This is the notion of 'related variety', } \\
\text { which is essential to understanding how to identify the regional capacity for developing new specializations. } \\
\text { Regardless, it is important to remember that smart specialization is also about developing new specializations } \\
\text { that help upgrade the local economy where there may be a lower number of technologically related industries } \\
\text { present. Institutional contexts in the sense of labor rights, corporate governance, and inter-firm collaboration are } \\
\text { all affecting the intensity and nature of relations between connected industries }\end{array}$ \\
\hline [Boschma, 2016] & Connectivity between and within regions \\
\hline [Boschma, 2013] & $\begin{array}{l}\text { A country's position as well as its regions' positions within global value chains, trade, and knowledge networks } \\
\text { are essential since regions that are better connected are able to enhance the economic effects of the local 'related } \\
\text { variety' }\end{array}$ \\
\hline [EUA, 2018] & $\begin{array}{l}\text { - Ensure enduring innovation by investing in human talent and skills. Investing in stronger links between } \\
\text { education, research, and innovation supports the development of human talent - the key success factor for } \\
\text { innovation. } \\
\text { - Enhance the strategic involvement of universities in regional innovation ecosystems. Fully engaging } \\
\text { universities in the entrepreneurial discovery process strengthens their ability to build networks and become a } \\
\text { strategic partner critical for regional systems. } \\
\text { - Promote the engagement of all regions without compromising excellence: ensure closure of the innovation gap } \\
\text { between regions through targeted funding } \\
\text { - Strengthen collaboration to induce innovation at the regional level: RIS3 is most effective when there is strong } \\
\text { cooperation between public authorities, universities, enterprises, and civil society. } \\
\text { - Develop mechanisms to provide opportunities for policy-makers, researchers and entrepreneurs to interact } \\
\text { and collaborate in the long term. } \\
\text { - Reinforce synergies and multi-level governance: improve the compatibility of and interaction between } \\
\text { regional, national, and European programs for R\&D. } \\
\text { - Comprehensive and joint multilevel approaches that rely on the principle of subsidiarity. }\end{array}$ \\
\hline
\end{tabular}

if they use the toolbox that EU experience provides and the payoffs of smart specialization can be huge if implemented effectively.

\section{An Overview of Brazil's Innovation Economy}

Although Brazil is the only country in Latin America to invest more than $1 \%$ of its GDP in $\mathrm{R} \& \mathrm{D}$, it places lower in the Global Innovation Index than comparably smaller economies like Chile, Costa Rica, and Mexico [Barroeta et al., 2017; Negri, 2018]. When analyzing other innovation indexes provided by the OECD and the World Bank ${ }^{1}$ it becomes clear that Brazil is also failing to catch up to other developed countries in terms of innovation output [Esteves, Feldmann, 2016; Faleiro et al., 2016]. The boom in Brazil's economic growth during the early 2000s (ca. 2000 - 2008) was mainly based on an increase in commodity exports and an expansion in domestic consumption [Cavalcante, Uderman, 2012; Ovanessoff, Peppes, 2015]. Since then, however, Brazil's productivity growth has been stagnating and its economy experienced a contraction rather than recovery from the global financial crisis in 2014 and the subsequent years given that structural problems were neglected during the economic boom [Maragna, 2016; Ovanessoff, Peppes, 2015]. Since 2010, Brazil's total fac- tor productivity has been negative, indicating that capital and labor assets are not being used well as a result of the growing inefficiencies in the Brazilian economy [Mazzucato, Caetano, 2016]. It is clear that promoting innovation is crucial for Brazil to overcome the growing inefficiencies.

\section{Governance in Brazil's STI System}

Brazil has a very expansive, complex, and fragmented network of government agencies and institutions that are responsible for the design, promotion, and execution of science and technology related policies. Covering the entirety of the Brazilian STI system in detail exceeds the scope of this paper. Therefore, the goal of this section is to provide the reader with a general overview of science and technology policymaking processes in Brazil.

The main bodies charged with $\mathrm{R} \& \mathrm{D}$ policy-making at the federal level are controlled by the national government, such as the Ministry of Science, Technology and Innovation (MCTIC) $)^{2}$, the National Council of Scientific and Technologic Development (CNPq), and the Coordination Bureau for the Improvement of Higher-Level Personnel (CAPES) [Barroeta et al., 2017; Maragna, 2016]. The strategic mission of the

Calculated on the number of patent applications, scientific publications, new business models, products or services and graduates in sciences, engineering and technology fields.

Hereinafter, in the text and figures when mentioning any Brazilian organization, institutional term or political initiative after the English-language name is given an abbreviation (if available) or the full name in the original language. For the full description see Table 3. 
Table 3. Definitions of Acronyms of Brazilian Organizations, Institutional Terms, and Policy Initiatives, Mentioned within the Text and Figures

\begin{tabular}{|c|c|c|}
\hline Acronym & Name in Portuguese & Name in English \\
\hline $\mathrm{ABC}$ & Academia Brasileira de Ciências & Brazilian Academy of Sciences \\
\hline $\mathrm{APL}$ & Arranjos Produtivos Locais & Local Productive Arrangements \\
\hline BNDES & Banco Nacional de Desenvolvimento Econômico e Social & Brazilian Development Bank \\
\hline CAPES & $\begin{array}{l}\text { Coordenação de Aperfeicoamento de Pessoal de Nível Supe- } \\
\text { rior }\end{array}$ & $\begin{array}{l}\text { Coordination for the Improvement of Higher Education Per- } \\
\text { sonnel }\end{array}$ \\
\hline $\mathrm{CNI}$ & Confederação Nacional da Indústria & Brazilian National Confederation of Industry \\
\hline $\mathrm{CNPq}$ & $\begin{array}{l}\text { Conselho Nacional de Desenvolvimento Científico e Tecno- } \\
\text { lógico }\end{array}$ & $\begin{array}{l}\text { National Council for Scientific and Technological Develop- } \\
\text { ment }\end{array}$ \\
\hline CONFAP & $\begin{array}{l}\text { Conselho Nacional das Fundações Estaduais de Amparo à } \\
\text { Pesquisa }\end{array}$ & Brazilian National Council for the State Funding Agencies \\
\hline CONSECTI & $\begin{array}{l}\text { Conselho Nacional de Secretários para Assuntos de Ciência } \\
\text { Tecnologia e Inovação }\end{array}$ & $\begin{array}{l}\text { Council of State Secretariats for Science, Technology and In- } \\
\text { formation Issues }\end{array}$ \\
\hline EMBRAPA & Empresa Brasileira de Pesquisa Agropecuária & Brazilian Agricultural Research Corporation \\
\hline ENCTI & Estratégia Nacional de Ciência, Tecnologia e Inovação & $\begin{array}{l}\text { Brazilian National Strategy for Science, Technology and In- } \\
\text { novation }\end{array}$ \\
\hline FAP & Fundação de Apoio à Pesquisa & State Funding Agency \\
\hline FAPEMIG & Fundação de Amparo à Pesquisa de Minas Gerais & Minas Gerais Research Foundation \\
\hline FAPERJ & Fundação de Amparo à Pesquisa do Estado do Rio de Janeiro & Rio de Janeiro Research Foundation \\
\hline FAPESP & Fundação de Amparo à Pesquisa do Estado de São Paulo & São Paulo Research Foundation \\
\hline FINEP & Financiadora de Estudos e Projetos & Funding Authority for Studies and Projects \\
\hline FNDCT & Fundo Nacional de Desenvolvimento Científico e Tecnológico & National Science and Technology Development Fund \\
\hline GTP-APL & $\begin{array}{l}\text { Grupo de Trabalho Permanente para Arranjos Produtivos } \\
\text { Locais }\end{array}$ & $\begin{array}{l}\text { Permanent Working Group for Local Productive Arrange- } \\
\text { ments }\end{array}$ \\
\hline IBICT & Instituto Brasileiro de Informação em Ciência e Tecnologia & Brazilian Institute of Information in Science and Technology \\
\hline IBN & Iniciativa Brasileira de Nanotecnologia & Brazilian Nanotechnology Initiative \\
\hline IPT & Instituto de Pesquisas Tecnológicas do Estado & Institute for Technological Research \\
\hline MAPA & Ministério da Agricultura, Pecuária e Abastecimento & Ministry of Agriculture, Livestock, and Supply \\
\hline MCTIC & $\begin{array}{l}\text { Ministério da Ciência, Tecnologia, Inovações e Comunica- } \\
\text { ções }\end{array}$ & $\begin{array}{l}\text { Ministry of Science, Technology, Innovation and Communi- } \\
\text { cation }\end{array}$ \\
\hline MDIC & Ministério da Indústria, Comércio Exterior e Serviços & Ministry of Industry, Foreign Trade and Services \\
\hline MEC & Ministério da Educação & Ministry of Education \\
\hline MEI & Mobilização Empresarial pela Inovação & Business Mobilization for Innovation Association \\
\hline MME & Ministério de Minas e Energia & Ministry of Mines and Energy \\
\hline MNI & Ministério da Integração Nacional & Ministry of National Integration \\
\hline MP & Ministério do Planejamento, Orçamento, e Gestão & Ministry of Planning, Budget, and Management \\
\hline MS & Ministério da Saúde & Ministry of Health \\
\hline PDP & Política de Desenvolvimento Produtivo & Productive Development Policy \\
\hline PITCE & Política Industrial, Tecnológica e de Comércio Exterior & Industrial, Technological and Foreign Trade Policy \\
\hline SBPC & Sociedade Brasileira para o Progresso da Ciência & The Brazilian Society for the Advancement of Science \\
\hline SEBRAE & Serviço Brasileiro de Apoio às Micro e Pequenas Empresas & Brazilian Service of Assistance to Micro and Small Enterprises \\
\hline SECTI & Secretários de Ciência Tecnologia e Inovação & Secretariats of Science, Technology and Innovation \\
\hline SENAI & Serviço Nacional de Aprendizagem Industrial & National Service for Industrial Training \\
\hline SNCTI & Sistema Nacional de Ciência, Tecnologia e Inovação & National System of Science, Technology and Innovation \\
\hline UFRJ & Universidade Federal do Rio de Janeiro & Federal University of Rio de Janeiro \\
\hline
\end{tabular}

National Bank for Economic and Social Development (BNDES) also includes the promotion of innovation development at local and regional level [Cavalcante, Uderman, 2012].

The STI System's central actor and coordinator is the Ministry of Science, Technology, Innovation, and Communication (MCTIC), which has legal powers and governs the National Science and Technology Development Fund (FNDCT) [Baer, 2012]. The MCTIC also oversees the Research and Innovation Fund (FINEP) and the National Council for Scientific and Technological Development (CNPq) to ensure that they implement their missions accordingly, which demonstrates that the MCTIC plays a major role in expanding, consolidating, and integrating Brazil's STI system. MCTIC is supported by other ministries when it comes to defining and executing the research budget and policies, such as the ministries of education (MEC), energy (MME), health (MS), agriculture (MAPA), foreign trade and industry (MDIC), and planning, budget and administration (MP) [Negri, 2018; Maragna, 2016]. The last is responsible for the research budgets planning and coordinating as it is part of the multi-year budgetary planning (plano pluriannual, PPA) [Mazzucato, Caetano, 2016]. The PPA has four strategic foci: quality education, social inclusion, increase in productivity, and strengthening public institutions [Mazzucato, Caetano, 2016]. Public funding for research then is allocated mainly from the four federal agencies CNPq, CAPES, FINEP, and BNDES as well as the 25 State Foundations. [Maragna, 2016]. $\mathrm{CNPq}$ supports research through national research scholarships, promoting the establishment of research groups and the creation of research networks of ex- 
Table 4. FAPESP's International Collaborators

\begin{tabular}{|l|l|}
\hline \multicolumn{1}{|c|}{ Organization } & Country \\
\hline UK Research Councils & UK \\
\hline $\begin{array}{l}\text { French National Research Agency (Agence } \\
\text { Nationale de Recherche, ANR) }\end{array}$ & France \\
\hline $\begin{array}{l}\text { German Research Foundation (Deutsche } \\
\text { Forschungsgemeinschaft, DFG) }\end{array}$ & Germany \\
\hline European Commission & EU \\
\hline National Science Foundation (NSF) & US \\
\hline National Institutes of Health (NIH) & US \\
\hline Department of Energy (DoE) & US \\
\hline \multicolumn{2}{|l}{ Source: compiled by the authors based on [FAPESP, 2018]. } \\
\hline
\end{tabular}

cellence [Barroeta et al., 2017]. CAPES is an essential actor in the expansion and consolidation of postgraduate studies, which is the 'sector' that produces most Brazilian research [Maragna, 2016]. FINEP and BNDES are more oriented toward business innovation. Venture capital projects in critical sectors (such as agriculture, energy, health, aerospace, other defense sectors, ICT, and sustainability) are financed by the Research and Innovation Fund (FINEP) [Cavalcante, Uderman, 2012]. Through its program execution, FINEP promotes three kinds of networks: a) the Networks of Innovation Centers; b) the Technology Services Network, and c) the Extension Technology Network for the promotion of technical support for innovation within states [Barroeta et al., 2017]. BNDES' tools are similar to FINEP's, but it operates with larger resources and on a broader national scale[Maragna, 2016].

Brazil's states are sub-national, autonomous entities that have their own governments and constitutions [Cavalcante, Uderman, 2012]. Out of the twenty-six states, twenty include a percentage of tax revenue intended for science and technology activities in their constitutions, while the remaining six set the percentage in a specific law or in their state budgets. Brazilian states have so-called 'Secretariats' of Science, Technology, and Innovation, which all meet jointly at the National Council of the Secretariats for Science, Technology, and Innovation (CONSECTI) [Mazzucato, Caetano, 2016]. Its purpose is to represent MCTIC in the states. CONSECTI functions as a non-profit private entity that advises the national bodies and coordinates and articulates shared interests of state STI agencies [Maragna, 2016]. Together with the National Council of State Research Foundations (CONFAP), comprised of twenty-five state research foundations (so-called Research Support Foundations (FAPs) stand out as SNCTI Development Agencies), these two entities are meant to support the coordination of Brazilian state governments' science and technology policies [Cavalcante, Uderman, 2012]. Other than these two forums, however, only a few regions in Brazil have their own innovation policy strategies that are backed by regional bodies to promote innovation and technological development [Barroeta et al., 2017]. Moreover, there are significant differences between the states in terms of technological development and regional innovation policy.

The Research Foundation of São Paolo (FAPESP) is one of the few examples in which a strategic, state-level body supports research and innovation across the region. FAPESP's activities such as financing for teaching, research, and innovation have been funded by an obligatory $1 \%$ of total state revenue [FAPESP, 2018]. The security of financial support and the autonomy granted to the foundation have had a sizable impact on the region of São Paulo: while only $22 \%$ of the total Brazilian population lives in the region, $30 \%$ of doctorate-level scientists reside there and it is responsible for $45 \%$ of the country's research publications in international journals [Maragna, 2016]. FAPESP also engages with other national and international research funding agencies, educational and research institutions as well as business enterprises through cooperation agreements (see examples in Table 4). In 2017, FAPESP disbursed $\mathrm{R} \$ 1.058$ billion (about \$PPP 523 million), 38\% of which funded basic research, $5 \%$ went to research infrastructure support, and 57\% were given to applied research projects [FAPESP, 2018]. Since the 1990s, similar strategies have been adopted by other states, which has contributed to an expansion of regional STI systems, but FAPESP remains the most active and bestendowed FAP, although the FAPs of Rio de Janeiro (FAPERJ) and Minas Gerais (FAPEMIG) have been gaining importance [DWIH São Paulo, 2018]. More recently, the federal government and the state governments have been working together to identify joint priorities for science and technology innovation in order to optimize the sharing of resources and generate more opportunities for collaboration at the grassroots level [Maragna, 2016].

Rules and regulations with respect to STI activities are created by the legislative branch, specifically the National Congress and the Brazilian State Assemblies [Cavalcante, Uderman, 2012]. The national STI system is enhanced by tax incentives, budgetary laws, and other government policies. As of 2015, the National System of STI has been included in the Constitution through Amendment 85 [Negri, 2018]. Therefore, Congress can now regulate the system and promote new debates and interactions between the actors in the STI environment [Maragna, 2016]. Both the Brazilian Academy of Sciences (ABC) and the Brazilian Society for the Advancement of Science (SBPC) play important roles in the development of legal instruments and coordination with the federal government [Mazzucato, Caetano, 2016]. The National Confederation of Industry (CNI) as well as the Business Mobilization for Innovation (MEI) represent two private sector entities in the national STI system [Mazzucato, Caetano, 2016].

As the Figure 1 below and the prior paragraphs demonstrate, the Brazilian STI system is very complex. ${ }^{3}$

\footnotetext{
The system is again in flux. The newly elected government of Jair Bolsonaro is largely restructuring the public administrative apparatus, with an extensive merger and reduction in the number of ministries, which would reorient the STI system of the country. At the time of this writing the new government was only a few days old, however, beginning the incorporation of its systemic imprint. The system described herein is the inherited one.
} 
Figure 1. Brazilian STI System

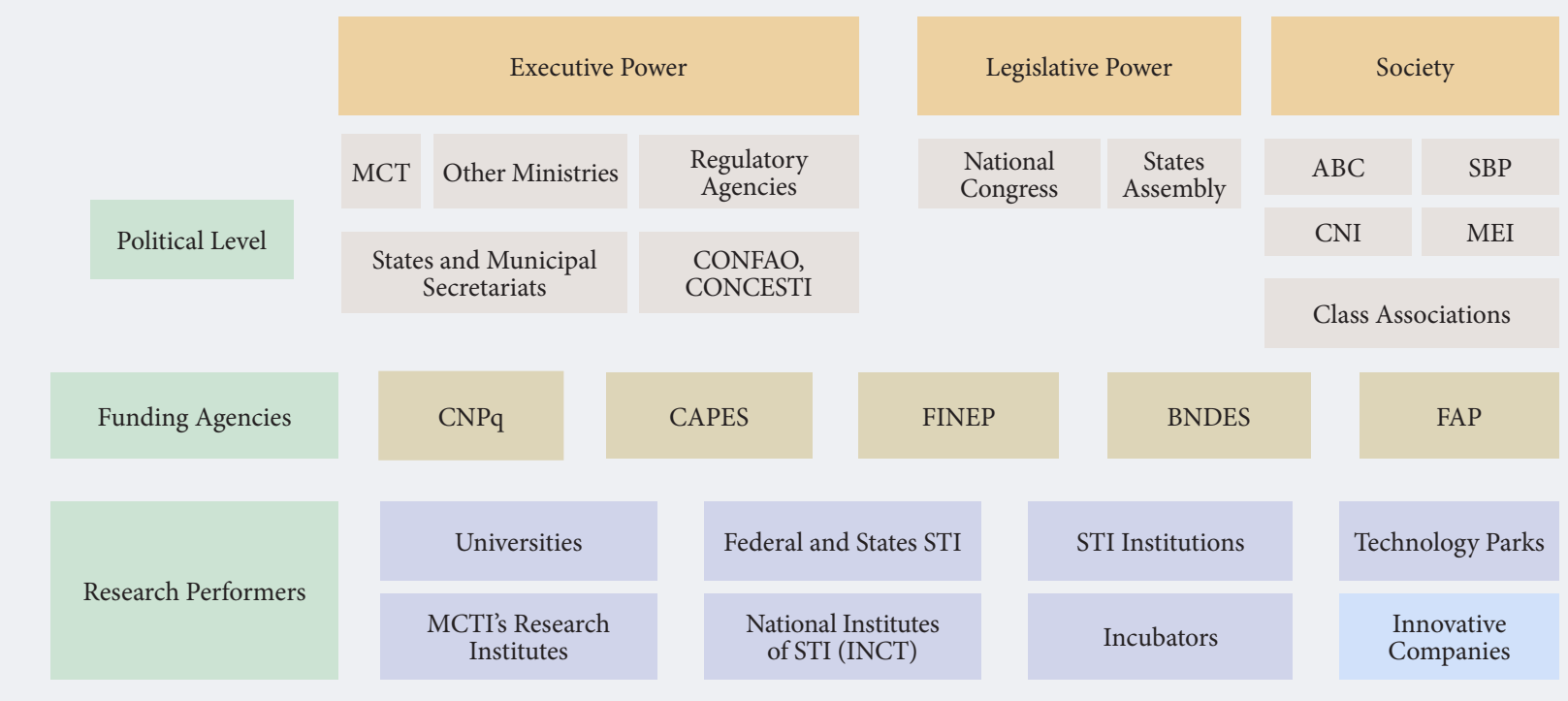

Source: compiled by the authors based on data from ENCTI 2016-2022 and [Maragna, 2016].

\section{Important STI Policies and the Current National Strategy (ENCTI 2016 - 2022)}

In Brazil, STI policies have played an increasingly important role in the federal government's adoption of industrial policy. In fact, the two primary industrial policies enacted during the 2000s were the "Productive Development Policy" (PDP, 2003) and the "Industrial, Technological, and Foreign Trade Policy" (PITCE, 2008) both highlighting the presumed importance of innovation for economic development [Maragna, 2016]. However, existing regional development policies do not seem to recognize innovation as a means for development. At the regional level, growth policies continue to attract uncoordinated investments through tax breaks and other financial incentives [Cavalcante, Uderman, 2012].

More recently, Brazil's innovation policies have concentrated more on creating better support for business R\&D [OECD, 2012]. The Greater Brazil Plan (2011), for example, adopted for the years 2011-2014 increases incentives for businesses to invest in $\mathrm{R} \& \mathrm{D}$ by giving innovation a central role and including some proposals for significant policy changes [Mazzucato, Caetano, 2016]. Additionally, the federal government launched the Science Without Borders Program to award more exchange and mobility fellowships/scholarships to students [Barroeta et al., 2017].

The first Brazilian National Strategy for Science, Technology, and Innovation (ENCTI) was launched in 2011 and published in 2012 with the overall goal being sustainable development driven by STI [Maragna, 2016]. In 2013, Brazil signed a major collaborative agreement with the EU for "scientific and coop- erative activities in fields of common interest" [Pinto, 2018]. Additionally, the Brazilian government created its Nanotechnology Initiative (IBN) in 2013, which is a public policy program that aims at making the Brazilian nanotechnology industry more innovative [DWIH São Paulo, 2018]. Although documents for a national Knowledge Platforms Program were signed in 2014, none of the planned 20 platforms have been established yet [Negri, 2018]. The idea was to use these platforms (in areas like agriculture, energy, health, ICTs, defense, protection of the Amazon, etc.) to increase communication between governmental agencies, private actors, and research institutions. Although the establishment of the knowledge platforms is lacking, the new Legal Framework for Science, Technology, and Innovation that entered into force in $2016^{4}$ now facilitates other forms of the cooperation and interaction between private and public actors within the STI system [Maragna, 2016].

Currently, the 2016-2022 National Strategy for Science, Technology, and Innovation (ENCTI) is being implemented by the MCTIC [Barroeta et al., 2017]. ENCTI 2016-2022 marks a milestone in the coordination of cross-cutting science and technology related public policies and private sector initiatives in Brazil [Pinto, 2018]. The new strategy is meant to continue and expand upon the efforts of earlier policy initiatives [Maragna, 2016]. It sets 11 priority areas: defense, climate change reduction of the impact of natural disasters, oceans, and Antarctica, sustainable urban systems, tackling gender inequality in research, an aging population, alternatives to animal testing, new production processes, information society and digital economy, energy, and technology convergence and 
enabling technologies. The priority areas are identified based on the OECD's Science, Technology, and Industry Outlook [OECD, 2014] as well as an analysis of Brazil's individual strengths and potential [Barroeta et al., 2017]. Moreover, the new ENCTI highlights the need to expand investments in innovation in order to achieve productivity gains and ensure the sustainable competitiveness of the Brazilian economy [Pinto, 2018]. To improve the institutional environment for innovative businesses, the strategy suggests creating forums for negotiation in order to establish rules of conflict with respect to intellectual property that could result from partnerships between research institutions and private businesses. The strategy also emphasizes the complexities in decreasing the regional inequalities in social inclusion, sustainable development, and the overall access to and production of STI. To this end, the strategy includes an analysis of all available human resources, existing infrastructure, and the progress made in the consolidation of local innovation systems. By responding to specific local demands, the strategy is meant to increase regional contributions to the overall success of large federal investments. With respect to regional innovation, the current strategy recognizes the importance of regional capacities and acknowledges the need to strengthen state-level stakeholders responsible for innovation and scientific progress. Rather than configuring actions related to the expansion in regional capacities by developing regional strategies, however, the strategy suggests the adoption of coordinated federal initiatives. This approach is meant to maximize the success of sectorial investments by planning and executing joint actions between regional (CONSECTI) and other key actors [MCTIC, 2016, Barroeta et al., 2017].

Brazil is also increasingly trying to encourage foreign participation. The National Institutes of Science and Technology supported 125 research development programs from 2009-2014 all over the country, promoting a productive modernization of the research infrastructure [FAPESP, 2018]. FINEP also implements an in frastructure funding program, CT-INFRA, which was created to support the modernization and expansion of infrastructure and research support services through the renovation of research facilities and the modernization of equipment. Brazil has been taking steps to modernize its research infrastructure through a variety of programs [DWIH São Paulo, 2018]. Moreover, the Brazilian government also issues tax waivers to incentivize the private sector to invest more in $R \& D$ activities as currently the federal and state government are the main investors (about 53\%, down from $57 \%$ in 2013) [Pinto, 2018]. Brazil's R\&D spending in 2016 was $1.27 \%$ of GDP, and although this is lower than in 2015 (1.34\% of GDP), spending had been steadily increasing since 2012 [MCTIC, 2018].

\section{Barriers to Innovation}

As mentioned in the previous sections, Brazil has an extensive network of science and technology policy actors and has been taking many steps to improve policymaking and improve innovation in recent years.
The innovation system has changed significantly over the last decade, but Brazil's innovation economy still seems not to be taking off. For one, geographic productivity across Brazil is very uneven and network-based research is low [Faleiro et al., 2016; Ovanessoff, Peppes, 2015]. The highly centralized innovation system presents a multitude of structural bottlenecks: the number of industry networks and those between local and regional authorities is too low, private sector research is not competitive, and government incentives (such as tax credits) only have a limited scope and reach [Esteves, Feldmann, 2016]. Additionally, it is still very complicated to 'do business' in Brazil and businesses are what drive innovation in most developed countries. While Brazil has been steadily improving in the World Bank's 'Doing Business' Indicators, it still ranks $125^{\text {th }}$ out of 160 countries, significantly behind Mexico $\left(49^{\text {th }}\right)$ and Chile $\left(5^{\text {th }}\right)$ and other countries in Latin America (including Costa Rica, El Salvador, Uruguay, Argentina, Ecuador,bnm and Paraguay) [World Bank Group, 2018]. This means that starting a business comes with a variety of bureaucratic obstacles, costly and lengthy processes of obtaining permits as well as intimidating labor regulations. The vast majority of businesses (about 72\%) still prefer to 'go at it alone' and avoid collaboration which can hinder innovative progress [Oliveira et al., 2014].

Moreover, skills shortages among Brazil's labor force is a key factor behind its low productivity levels: $65 \%$ of businesses find it difficult to hire high-skilled workers, which hinders their productivity [Negri, 2018]. Related to this issue is the significant gap that exists between universities and industry and the lack of interaction and collaboration between the two [Esteves, Feldmann, 2016; Negri, 2018]. The fact that academic researchers are disconnected from commercialized R\&D and innovation constitutes a key weakness in Brazil's innovation system. Brazil's traditional approach of statesupported industrial development represents another barrier to innovation in the private sector: they are not motivated to push the boundaries because they have been able to grow regionally without becoming more innovative through strong Brazilian customer demand [Esteves, Feldmann, 2016; Mazzucato, Caetano, 2016]. As this is ebbing away, so is their growth. Outside of the state-supported industries, businesses mainly acquire foreign technology that they adapt for local and regional markets.

In a paper by Mariana Mazzucato and Penna Caetano [Mazzucato, Caetano, 2016], the authors identify four subsystems (see graph below) in the Brazilian innovation system and their weaknesses and strengths. According to their analysis, Brazil lacks a 'consistent long-term strategic agenda' and a coherent vision that gives direction to the public policies and research carried out by different institutions and private actors. They also find that the Brazilian innovation system is so fragmented that sometimes antagonism is displayed between the actors in the subsystems of education, research, innovation, and production. This antagonistic behavior is due to the self-orientation of scientific research and lack of business demand for knowledge pro- 


\section{Figure 2. Basis of the Brazilian STI System}

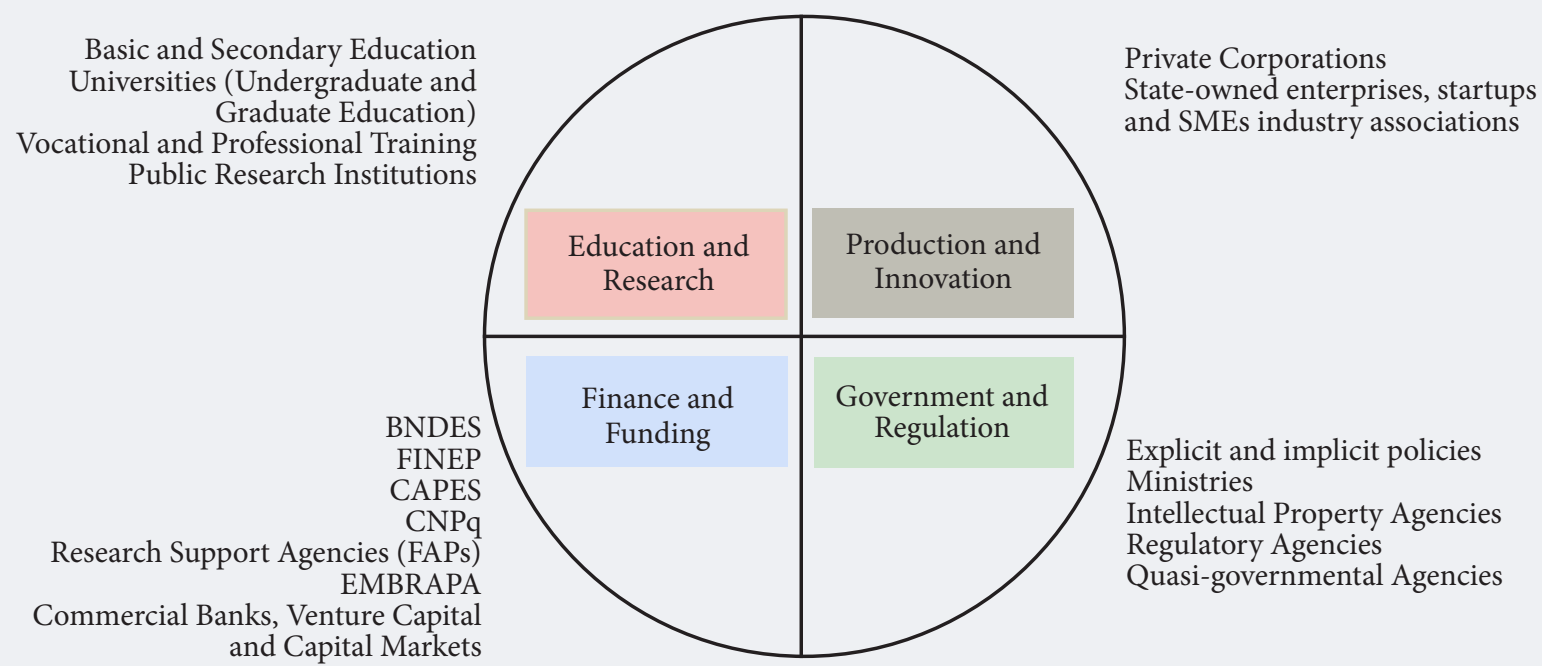

Source: compiled by the authors based on [Mazzucato, Caetano, 2016].

duced by academia. Additionally, within the subsystem of innovation and production, the authors emphasize the low levels of business expenditures on R\&D as a reason for Brazil's low propensity to innovate. Within the subsystem of policy and regulation, their research finds inefficiencies in terms of "overlapping responsibilities, competition for the use of resources, discontinuity for investments and programs, and excessive bureaucracy". Lastly, they assert that the Brazilian innovation system requires institutional reforms with respect to the regulation and taxation of businesses as well as a revision of the macroeconomic agenda and implicit policies thereof that negatively affect the innovation system [Mazzucato, Caetano, 2016].

In her new book Novos Caminhos Para a Inovação no Brasil (New Paths Toward Innovation in Brazil), economist Fernanda De Negri explores why Brazil has not been able to achieve significant improvements in its innovative performance despite several new policies [Negri, 2018]. The only exception was scientific production (publications), in which Brazilian participation jumped from $0.7 \%$ to $3 \%$ since the late 1990 s. However, the publications did not improve in quality at a similar rate. De Negri identifies overarching factors that contribute to innovative capacity: 1) well-trained and educated citizens, particularly scientists and engineers, 2) infrastructure that meets the requirements of high-level research, and 3) an overall environment that favors innovation and scientific production. She highlights the following barriers to innovation within the three areas (see Table 5).

In a study by Esteves \& Feldmann [Esteves, Feldmann, 2016] the authors investigate why Brazil does not innovate compared to other regions. They highlight the lack of public investments in issues relevant to innovation, businesses' lacking commitment to innovation, and the bad cooperation/integration of universities, research centers, and the private sector. They conclude that a broader government commitment is necessary for Brazil to enhance public expenditures on $R \& D$ to increase innovation and the production of high-tech goods. Moreover, they suggest that Brazil should take

\section{Table 5. Barriers to Innovation, by Area}

\begin{tabular}{|l|l|}
\hline \multicolumn{1}{|c|}{ Area } & \multicolumn{1}{c|}{ Barriers } \\
\hline Education & $\begin{array}{l}\text { - The ratio of scientists and engineers to the population is lower than in most other developed countries } \\
\text { - While access to education in Brazil has risen, its quality has not } \\
\text { - Brazilian science is not satisfactorily internationalized } \\
\text { - The issue today is Brain Circulation, not Brain Drain }\end{array}$ \\
\hline Infrastructure & $\begin{array}{l}\text { - Brazil lacks the infrastructure to conduct cutting-edge, multidisciplinary research } \\
\text { - Brazil has not sufficiently diversified its research system } \\
\text { - Public universities' bureaucracy is an obstacle to cutting-edge research }\end{array}$ \\
\hline $\begin{array}{l}\text { Policy } \\
\text { Environment }\end{array}$ & $\begin{array}{l}\text { - The closing off of the Brazilian economy is an obstacle to innovation } \\
\text { - Access to cutting-edge technologies is limited for Brazilian companies } \\
\text { - Economic restrictions hinder Brazilian participation in global production networks and reduce competition }\end{array}$ \\
& $\begin{array}{l}\text { - Vis-à-vis other developed countries, the cost of capital is too high and venture capital markets are } \\
\text { - The Brazilian business environment is too complex and bureaucratic }\end{array}$ \\
\hline \multicolumn{2}{|l}{ Source: compiled by the authors based on [Negri, 2018]. } \\
\hline
\end{tabular}


measures to strengthen cooperation and increase interaction between research centers, universities, and companies [Esteves, Feldmann, 2016].

\section{Smart Specialization in Brazil}

Smart specialization is of great interest to Brazil, a country with vast differences in regional economic development. As we have seen in the previous section, a RIS3 strategy generates opportunities for development partnerships and can be a catalyst for regional development. By adopting a system view, smart specialization can be a useful tool to structure regional innovation policy formulation. The combination of investment in soft capital (internationalization and collaboration) and in infrastructure makes RIS3 an effective strategy to capitalize on existing potential in the region. Such a strategy has to be developed, competitive advantages and strategic priorities have to be identified, and ultimately policies need to be implemented.

\section{The Current State of Smart Specialization in Brazil}

Adopting an RIS3 strategy means putting the concept of smart specialization into practice, beginning with a shared vision to transform local economies into more competitive, sustainable, and long-term successful regions [McCann, Ortega-Argilés, 2016a]. In Brazil, smart specializations thus far seem to be limited to cooperative efforts with the EU. The bilateral framework between the two includes an agreement for scientific and technological cooperation, a roadmap for EU-Brazil Scientific and Technological Cooperation, and the European Research Council Implementing Agreement signed by CONFAP [Pinto, 2018]. Most importantly, the sectorial dialogue between the European Union and Brazil has been supporting efforts to implement smart specialization in Brazil [Barroeta et al., 2017]. Examples of EU projects and activities in Brazil are [Haberleithner et al., 2018]:

- the EU-CELAC Joint Initiative on Research and Innovation,

- the International Urban Cooperation Project,

- the EU-CELAC Common Research Area,

- INNOV-AL (the promotion of decentralized innovation policies in the states of Paraná, Pernambuco, and Pará),

- INCOBRA (increasing and enhancing Research \& Innovation Cooperation Activities between Brazil and European Union R\&I actors, so that both regions get the best value out of mutual cooperation)

- CEBRABIC-ENRICH (Network of Research and Innovation Centers and Hubs).

By funding the 'Bases for the Implementation of a Regional Innovation System in Pernambuco State' the EU-Brazil Sectorial Dialogue has launched a pilot action to introduce smart specialization to Brazil [Maragna, 2016]. The EU Commission has provided the Brazilian Ministries of National Integration (MNI) and Science and Technology (MCTIC) with the expertise on methodology and helped to establish an inclusive participatory process to define a regional context of innovation as the basis of a smart specialization strategy [European Commission, 2017, Barroeta et al., 2017]. The EU also supports pilot programs in the economic sector related to garments in the municipality of Caruaru and in the sector of high-tech automotive components in the state of Goiás and the city of Recife [Maragna, 2016]. Thus far the participation of the textile sector has been considered very satisfactory, while there has been a noted lack of enthusiasm from automotive companies [Barroeta et al., 2017]. The driving factors behind these different developments may be diverging levels of practical and tacit knowledge and degrees of financing and institutional support [Pinto, 2018].

One of the first projects on smart specialization that Brazil is working on by itself is the Brasilia 2060 experimental project, an effort at cooperation in science and technology with smart specialization as a key element for regional developments in the metropolitan area of Brasilia [IBICT, 2013; Barroeta et al., 2017]. This project is led by the Brazilian Institute of Information in Science and Technology, which is a research unit connected to the MCTIC. The designed RIS3 strategy for the region values its competitive advantages and specific innovative potential [IBICT, 2018]. To facilitate the design process, the IBICT recently launched a Smart Specialization Platform [EU Brazil Sector Dialogues, 2018]. The platform is supposed to serve as a way to distribute information, results, and findings of the smart specialization aspects in the Brasilia 2060 project. While it is obviously much too early to judge the success of these ongoing projects in Brazil, there are a lot of promising developments.

\section{Where Does Smart Specialization Fit into Brazil's National SeT Policy Environment?}

In a country like Brazil with huge regional inequalities, the reduction of these imbalances is a critical challenge. To this end, there is a concept in Brazil, that, similarly to smart specialization, aims at improving local development - Local Productive Arrangements (APLs). APLs are the Brazilian version of clusters: companies and enterprises located in the same region that are interlinked and represent a coordinated productive specialization [Alderete, Bacic, 2018]. They are tied together by some type of governance agreement, interact and cooperate with each other, and learn from one another or other local actors such as governments, research institutions, business associations, or funding institutions [MDIC, 2018].

There is a permanent working group (GTP-APL) that is coordinated by Brazil's Ministry of Industry, Foreign Trade, and Services (MDIC), which was set up to increase the integration between different actors, articulate policies, and promote APLs at the federal level [MDIC, 2018]. Specifically, it is responsible for identifying local APLs across the country, defining criteria for joint governmental action to support those APLs, building an information system for the management of APLs, and elaborating a term of reference for relevant conceptual and methodological aspects of APLs. The working group consists of 34 national governmental 
and non-governmental institutions, 12 of which are government ministries. There are also 27 State Support Centers for APLs to improve communication between the working group and the actual APLs at the local level. In the support centers, there are representatives from the state government, system S, financial institutions, the business sector, the C\&T system and employees of firms who are participating in APLs [MDIC, 2018]. The PPA 2016-2019 of the federal government recommends supporting APLs to promote the consolidation of national production chains, technological improvement, and sales of goods and services [Maragna, 2016]. Within APLs, there is a difference between productive and innovative arrangements. A productive APL targets economy of scale and scope, as well as improvements in quality and productivity. An innovative APL on the other hand aims at decreasing risk, cost, and time while increasing interactive learning and innovative potential [Alderete, Bacic, 2018]. APLs are mainly supported by the Research Network Systems of APLs, an interdisciplinary research network based at the University of Rio de Janeiro, the National Research Council (CNPq), FINEP, SEBRAE, SENAI, IPTs, and the Embrapa [MDIC, 2018] cluster. As of 2015, the APL working group had recognized 677 APLs across Brazil [MDIC, 2018].

Basically, these APL support measures are what is known as cluster policies. The rationale of clusters overlaps with that of smart specialization, however, clusters apply to broader sets of sectors in an economy, whereas smart specialization focuses on innovation-intensive sectors. The most significant difference is in the end the goal of the two concepts: cluster policies aim to boost the performance of already existing clusters while smart specialization strategies are designed to discover new knowledge-based activities and domains in order to transform regional economies [Ketels et al., 2013; Asheim, 2018].

So, while RIS3 policies are implemented to transform regional innovation ecosystems, clusters represent elements of those ecosystems. If they generate new knowledge spillovers that have effects on the growth path of the regional economy, clusters could potentially be a 'smart specialization domain'. Thus, cluster regions are obviously very important to smart specialization strategies [Ketels et al., 2013]. Due to a lack of robust measurement tools, it is difficult to draw lessons from Brazil's APLs for regional development. Alderete and Bacic [Alderete, Bacic, 2018] construct a composite index to measure local development in the municipalities in the state of Sao Paulo. They find that in the $19 \%$ of municipalities with APLs, local development is slightly better than in those without APLs [Alderete, Bacic, 2018]. This result is an encouraging sign that clusters and cluster policies can be a key building block for countries trying to design smart specialization strategies, especially Brazil.

Over the last decade, Brazil has been taking many steps toward create an innovation friendly environment. In its PPA 2016-2019 budget, it sets four priorities (quality education, social inclusion, productivity improvements, and the strengthening of public institutions), of which three are factors that can help smart specialization succeed and one (productivity improvements) is the desired result [Pinto, 2018]. Similarly, FINEP's initiative of promoting networks of innovation, technology services, and the extension of technology could present a good opportunity to encourage cross-sectoral collaboration that is necessary for a successful RIS3 strategy at the federal level. The ENCTI 20162019 makes many very important points: it emphasizes regional inequalities and the complexities of resolving them and highlights the need to expand innovation and R\&D spending to increase productivity [MCTIC, 2016]. Additionally, the analysis includes the suggestion that the ENCTI could be useful for designing a future RIS3 strategy for Brazil. Evidently, Brazil seems to be moving in the right direction at the federal level.

At the regional level, Brazil's biggest strengths are the CONSECTI and the CONFAP. With more emphasis on their significance and greater financial assistance, they could be useful tools to encourage more activity by other FAPs. For example, they could do so by requiring $1 \%$ of revenue for FAP funding so they can catch up to the FAPESP. These regional actors could also be a great opportunity to promote the development of individual regional innovation policy strategies such as making a regional plan a requirement for receiving funding like the EU does. In terms of federal-level policies, it would be useful for those bills to refocus on innovation as a means for development so that investments can be better coordinated and concentrated via well-structured tax breaks and other financial incentives.

Brazil has strengths that it can capitalize upon, such as the existence of a developed and expansive innovation system with key institutions in each sub system. Moreover, there have been significant improvements in the Brazilian system of scientific research that has produced cutting-edge knowledge in key areas like agriculture, health, oil and gas, and aviation [Pinto, 2018]. With its abundance of strategic natural resources, Brazil is well placed to move forward in the process of economic inclusion. Brazil's multitude of agencies that are devoted to supporting and executing STI policies and its strong domestic consumer market are helpful assets in its endeavor do become a top innovator [Negri, 2018]. With respect to public financial resources for $\mathrm{R} \& \mathrm{D}$, it is an advantage that they are not affected by budgetary fluctuations as they come from the BNDES and not the Treasury [Mazzucato, Caetano, 2016]. There have been successful examples of systemic policy initiatives in the past that focused on innovation and led to improved cooperation between academia, businesses, and the public sector such as the INOVA program [Mazzucato, Caetano, 2016]. Such initiatives can serve as a model for future activities.

However, there are specific challenges to be overcome in Brazil, and Latin America as a whole, when it comes to the implementation of a smart specialization strategy. Both human and technical capital constraints in the public and private sector play an important role. Moreover, little cooperation and low trust levels characterize the relationships between public research institutes, universities, and private sector actors [Faleiro 
et al., 2016]. Accountability, and the lack thereof, constitutes another fundamental issue, as the information on impacts and deliverables of specific innovation policies are scarce, especially at the regional level. In Brazil, but also in many other countries in Latin America, institutional configurations are characterized by highly centralized structures and a lack of political will and financial resources to promote decentralized S\&T strategies, such as RIS3 [Barroeta et al., 2017]. To this end, the EU's engagement in Brazil is very helpful. The RIS3 pilot in Pernambuco could help Brazil overcome some of these limitations or minimize their impact.

In the European Union, member states have had quite different experiences with smart specialization strategies, but thus far the results have shown that a strategic concentration of resources and definition of specific priorities based on smart specialization theory can result in the stimulation of innovation and knowledge production [McCann, Ortega-Argilés, 2016b]. Collaborative activities between industry and universities, internationalization, and the creation of new technology-driven businesses have supported job growth and the establishment of value chains that create greater added value across European regions [EUA, 2018]. As a result, these findings could make RIS3 strategies more attractive to Brazil and may catalyze political and financial will. Regardless, there have also been issues with implementing RIS3 in Europe, many resulting from deficits in public administration and a lack of local RIS3 facilitators to promote key projects and design monitoring mechanisms [Kotnik, Petrin, 2017; Kroll, 2014; Landabaso et al., 2014]. Such issues could obviously also become a problem for implementation in Brazil. Therefore, an in-depth process is needed for the initial creation of a RIS3 strategy in order to generate evidence that the policies can be based on. Moreover, it is crucial that all innovation system actors are empowered and encouraged to participate in the RIS3 strategy. It seems that some regions in Brazil are working on these steps.

Furthermore, there are a variety of structural limits that need to be addressed before a smart specialization strategy can be implemented successfully. Unlike the EU, Brazil lacks a cross-cutting policy instrument like the European Cohesion Policy. This policy allows the EU to undertake large-scale financing of government interventions in the priority areas selected for smart specialization [Bachtler et al., 2017]. Therefore, the differences in institutional structures, economic performance, social innovation needs, and technological intensity between the southern and northern regions of Brazil must be taken into account when designing an RIS3 approach for the whole country. Moreover, to eliminate the risk of public S\&T actors or other powerful special interests, such as multinational companies or other dominant scientific research institutions, constraining the choices of RIS3 priorities, the domains of top-down and bottom-up innovation through entrepreneurial discovery must be defined very carefully [Gheorghiu et al., 2017]. As seen in the region of Pernambuco, evidence-based policy-making is crucial and therefore, more evidence is needed to promote smart specialization and the methodologies of entrepreneurial discovery and ultimately gain public understanding and support for the potential of smart specialization in Brazil.

\section{Specific Lessons for Brazil}

Some of the barriers to innovation identified in this research overlap with some of the limits of designing and successfully implementing a smart specialization strategy. The main obstacles to innovation in Brazil that need to be addressed are uneven geographic productivity, structural bottlenecks due to a highly centralized system, the difficulty of 'doing' business, skills shortages, low levels of collaboration between industry and universities, the lack of a long-term strategic agenda, a fragmented STI system, low business expenditures on $R \& D$, the lack of scientific infrastructure and the diversification of research and industry, and lastly, huge bureaucratic structures and a closedoff economy [Faleiro et al., 2016; Ingold et al., 2015; Mazzucato, Caetano, 2016; Negri, 2018; Ovanessoff, Peppes, 2015; Negri, 2018]. The proposals to overcome these obstacles are summarized at Table 6 .

Smart specialization should be seen as a complement to these suggestions. Smart specialization could help to achieve some of these recommendations, if they are implemented, they could increase the chances of successfully carrying out a smart specialization strategy. As of now there is only the smart specialization implementation in Pernambuco and plans to design a strategy for Brasilia. A strategic vision for Pernambuco to be transformed into a region that truly has the capacity to generate better jobs, attract talent, and produce high value-added goods and services using innovative approaches and scientific knowledge could propel it to becoming one of the most competitive regions in Brazil and help to strengthen the overall economy.

As of now, it seems that some conditions for smart specialization to succeed are present in Brazil while others are lacking. Brazil is moving in the right direction with many important policy initiatives at the federal level and increasing engagement with regional actors. The Brazilian innovation system has many strengths that it can capitalize on, which makes it possible to eventually reach a point where smart specialization can be the optimal strategy to advance the economy. Building on its existing APLs, the insights generated in Phase 2 of the Pernambuco RIS3 implementation, and the Brasilia 2060 project can help Brazil to design its own RIS3 strategy and build a new public policy paradigm for science and innovation policy.

\section{Conclusions}

Smart specialization is designed to address some of the issues and barriers many developing and emerging countries face with respect to promoting innovation such as uneven geographic productivity, structural bottlenecks, and the diversification of research. However, many of these barriers are contextual and regionally specific issues that go beyond what smart spe- 


\section{Table 6. Proposals on Increasing the Performance of the Brazil's Innovation System}

\begin{tabular}{|c|c|}
\hline Tasks & Proposed steps \\
\hline $\begin{array}{l}\text { Improving the business climate } \\
\text { in Brazil in order to boost } \\
\text { industrial performance }\end{array}$ & $\begin{array}{l}\text { - Consolidating taxes at federal and state levels to ultimately have one value added tax } \\
\text { - Installing refunds for input VAT paid and zero-ratings for exports } \\
\text { - to encourng the levels of trade protection by lowering tariffs and scaling back local content requirements } \\
\text { - Streamlining regulationalization on product markets to strengthen competition } \\
\text { - Improving the technical capacity } \\
\text { - Planning for infrastructure } \\
\text { Expanding the enrollment in vocational training in order to decrease labor shortages for technical } \\
\text { workers }\end{array}$ \\
\hline $\begin{array}{l}\text { Improving cooperation and } \\
\text { interactions between different } \\
\text { innovative actors not only in } \\
\text { the private and public sectors } \\
\text { but also in the different } \\
\text { territorial systems }\end{array}$ & $\begin{array}{l}\text { - More participatory governance process of the innovation system that involves all stakeholders, } \\
\text { including businesses, government, universities, and society } \\
\text { - Connecting a potential RIS3 framework to ongoing policies, such as ENCTI's or FINEP's } \\
\text { promotion of networks } \\
\text { - Creating incentives for RIS3-identified partnerships by expanding financial and advisory support } \\
\text { for such proposals }\end{array}$ \\
\hline $\begin{array}{l}\text { Strengthening the scientific } \\
\text { base as well as Brazilian } \\
\text { universities }\end{array}$ & $\begin{array}{l}\text { - Investing in multi-use, publicly-supported, and flexible research institutions } \\
\text { - Promoting diversity and internationalization at universities } \\
\text { - Strengthening academic excellence through the specialization of institutions }\end{array}$ \\
\hline $\begin{array}{l}\text { Improving the systemic and } \\
\text { institutional conditions of } \\
\text { innovation }\end{array}$ & $\begin{array}{l}\text { - Greater integration into global value chains } \\
\text { - More economic openness and broader access to new technologies } \\
\text { - Secreasing in the cost of capital for investments in innovation } \\
\text { - Downsizing the bureaucracy that characterizes the business environment }\end{array}$ \\
\hline Public policy enhancement & $\begin{array}{l}\text { - Implementing mechanisms to evaluate science and technology policies } \\
\text { - Using science and technology as a driving force to resolve problems } \\
\text { - Eiversifying the institutions and mechanisms that support science and technology in Brazil } \\
\text { and innovation sector }\end{array}$ \\
\hline
\end{tabular}

cialization can achieve, but they are simultaneously required to be resolved in order for RIS3 to succeed. For example, low levels of collaboration, lack of scientific infrastructure and the bureaucracy/difficulty of doing business can all be factors that hinder the progress of smart specialization. Reducing the bureaucracy of the public sector in Brazil, for example, to improve the 'doing business' indicators would therefore be advantageous for the implementation of RIS3 strategies. Such progress also requires investing in human resources, talent, and skills as well as strong links between education and research - especially the strategic involvement of universities in the entrepreneurial discovery process and in regional innovation ecosystems. Moreover, the engagement of all regions and multi-level governance (subsidiarity) are helpful for the success of an RIS3 strategy as opposed to the common centrality of STI systems in emerging countries as exemplified by the Brazilian case. Priority and domain setting as well as the promotion of innovation at the state level could either be optimized by creating specific regional animators or by emphasizing the need for more regional encouragement in the existing system. Lastly, it would be useful for the conditions of government initiatives to be structured in a way that transcends political cycles so that long-term goals can be achieved.

Smart specialization can be a very interesting and useful framework to stimulate development and growth in Brazil and other countries, but it is only realistic if it builds upon the country's existing strengths, such as Brazil's APL system and if respective policies are ultimately implemented successfully. For that to happen, however, a RIS3 strategy must be carefully planned and the government agencies have to reflect carefully on the future of innovation and the structure of regional policy in the country in question.

Designing and implementing an RIS3 strategy is very expensive and in the Brazilian case, that money may be better spent on addressing other issues at this point in the process. We believe that such an approach would be appropriate for other countries at similar stages of economic development considering RIS3 strategies. As creating an environment in which businesses and new ideas can thrive has become the key to sustaining a country's competitiveness, the findings of this paper may be relevant for any country looking to boost its innovation economy.

The authors acknowledge the infrastructural support of the Institute for International Science and Technology Policy at the George Washington University. Nick Vonortas acknowledges support by the São Paulo Research Foundation (FAPESP) in connection to the São Paulo Excellence Chair in Innovation Systems, Strategy and Policy (InSySPo) at the University of Campinas (UNICAMP). He also acknowledges support from the Basic Research Program at the National Research University Higher School of Economics within the framework of the subsidy to HSE by the Russian Academic Excellence Project '5-100'. None of these organizations are responsible for the content of this paper. Remaining mistakes and misconceptions are solely the responsibility of the authors. 


\section{References}

Alderete M.V., Bacic M. J. (2018) Local Productive Arrangements and Local Development in Non-Metropolitan Municipalities of Sao Paulo, Brazil. Cuadernos De Gestión, vol. 18, no 1, pp. 103-123.

Asheim B., Grillitsch M., Trippl M. (2017) Smart Specialization as an Innovation-Driven Strategy for Economic Diversification: Examples From Scandinavian Regions. Advances in the Theory and Practice of Smart Specialization (eds. S. Radošević, A. Curaj, R. Gheorghiu, I. Wade), Amsterdam: Academic Press, pp. 73-97. Available at: https://doi.org/10.1016/B978-0-12-804137-6.00004-8, accessed 21.02.2019.

Asheim B.T. (2018) Smart specialisation, innovation policy and regional innovation systems: What about new path development in less innovative regions? Innovation: The European Journal of Social Science Research, vol. 32, no 1, pp. 8-25. Available at: https://doi.org/10.1080/ 13511610.2018.1491001, accessed 27.02.2019.

Bachtler J., Berkowitz P., S. Hardy (eds.) (2017) EU cohesion policy: Reassessing performance and direction, London, New York: Routledge, Taylor \& Francis Group.

Baer W. (ed.) (2012) The regional impact of national policies: The case of Brazil, Cheltenham: Edward Elgar.

Balland P.-A., Boschma R., Crespo J., Rigby D.L. (2018) Smart specialization policy in the European Union: Relatedness, knowledge complexity and regional diversification. Regional Studies, vol. 35, no 4, pp. 1-17. Available at: https://doi.org/10.1080/00343404.2018.1437900, accessed 21.02.2019.

Barroeta B., Gómez Prieto J., Paton J., Palazuelos M. (2017) Innovation and Regional Specialisation in Latin America: Identifying conceptual relations with the EU Smart Specialisation approach. Luxembourg: JRC EC. Available at: https://ec.europa.eu/jrc/sites/jrcsh/files/innovation_ and_regional_specialisation_latinoamerica.pdf, accessed 17.02.2019.

Boschma R. (2013) Constructing Regional Advantage and Smart Specialization: Comparison of Two European Policy Concepts (Evolutionary Economic Geography Series Paper no 13.22), Utrecht: University of Utrecht.

Boschma R. (2016) Smart Specialisation and Regional Innovation Policy. Welsh Economic Review, vol. 24, p. 17. Available at: https://doi. org/10.18573/j.2016.10050, accessed 15.01.2019.

Cavalcante L.R., Uderman S. (2012). Science, technology and innovation policies in the regional development of Brazil. The regional impact of national policies: The case of Brazil (ed. W. Baer), Cheltenham: Edward Elgar, pp. 98-121.

Crespo J., Balland P.-A., Boschma R., Rigby D. (2017) Regional Diversification Opportunities and Smart Specialization Strategies, Brussels: European Commission.

DWIH São Paulo (2018) Brazil — Research Funding. Available at: https://dwih.com.br/en/brazil-research-funding, accessed 25.01.2019.

Esteves K., Feldmann P.R. (2016) Why Brazil does not innovate: A comparison among nations. RAI Revista De Administração E Inovação, vol. 13, no 1, pp. 29-38. Available at: https://doi.org/10.1016/j.rai.2016.04.002, accessed 16.12.2018.

EU Brazil Sector Dialogues (2018) Brazil unveils Smart Specialisations platform in a workshop during European Week of Regions and Cities. Available at: http://www.sectordialogues.org/new/brazil-unveils-smart-specialisations-platform-in-a-workshop-during-european-week-ofregions-and-cities, accessed 02.12.2018.

EUA (2018) Coherent Policies for Europe Beyond 2020: Maximising the Effectiveness of Smart Specialisation Strategies for Regional Development, Brussels: European University Association. Available at: https://eua.eu/component/attachments/attachments.html?id=376, accessed 16.01.2019.

European Commission (2017) Reflection Paper on Harnessing Globalisation, Brussels: European Commission. Available at: https://ec.europa.eu/ commission/sites/beta-political/files/reflection-paper-globalisation_en.pdf, accessed 19.01.2019.

European Commission (2018a) Smart Specialisation and Technology Transfer as Innovation Drivers for Regional Growth (Summary Report on the conference held in Sofia, May 3-4, 2018), Sofia: European Commission. Available at: https://ec.europa.eu/jrc/sites/jrcsh/files/summaryreport_conf_innovation-drivers-regional-growth.pdf, accessed 25.01.2019.

European Commission (2018b) Pilot Action - Regions in Industrial Transition (Project Leaflet by Directorate-General for Regional and Urban Policy), Brussels: European Commission. Available at: https://ec.europa.eu/regional_policy/sources/docgener/informat/industrial_ transition/pilot_industrial_transition.pdf, accessed 15.01.2019.

European Commission (2018c) Smart Specialisation - Pilot Actions (Project Leaflet by Directorate-General for Regional and Urban Policy), Brussels: European Commission. Available at: http://europa.eu/rapid/attachment/IP-17-1995/en/SmartSpecialisation_PilotActions.pdf, accessed 15.01.2019.

European Commission (n.d.) Smart Specialisation - Strenghtening Innovation in Europe's Regions (Project Leaflet by Directorate-General for Regional and Urban Policy), Brussels: European Commission. Available at: http://ec.europa.eu/regional_policy/sources/docgener/guides/ smart_spec/strength_innov_regions_en.pdf, accessed 15.01.2019.

Faleiro F., Ovanessoff A., Plastino E. (2016) Why Brazil Must Learn to Trust in Collaborative Innovation, Sao Paolo: Accenture. Available at: https://www.accenture.com/t20170411T180335Z__w__/us-en/_acnmedia/PDF-32/Accenture-Why-Brazil-Must-Learn-To-Trust-InCollaborative-Innovation-Executive-Summary.pdfla=en, accessed 13.01.2019.

FAPESP (2018) About the São Paulo Research Foundation. Available at: http://www.fapesp.br/en/about, accessed 22.12.2018.

Foray D. (2015) Smart Specialisation - Opportunities and Challenges for Regional Innovation Policy (1 $1^{\text {st }}$ ed.), London: Routledge.

Foray D. (2016) On the policy space of smart specialization strategies. European Planning Studies, vol. 24, no 8, pp. 1428-1437. Available at: https://doi.org/10.1080/09654313.2016.1176126, accessed 06.02.2019.

Foray D. (2017) The Economic Fundamentals of Smart Specialization Strategies. Advances in the Theory and Practice of Smart Specialization (eds. S. Radošević, A. Curaj, R. Gheorghiu, I. Wade), Amsterdam: Academic Press, pp. 37-50. Available at: https://doi.org/10.1016/B978-012-804137-6.00002-4, accessed 12.02.2019.

Foray D., David P.A., Hall B.H. (2011) Smart specialization: From academic idea to political instrument, the surprising career of a concept and the difficulties involved in its implementation (MTEI Working Paper), Lausanne: Ecole Polytechnique Federale de Lausanne.

Foray D., Goenaga X. (2013) The Goals of Smart Specialisation (JRC Scientific and Policy Reports - S3 Brief Series no 1), Brussels: European Commission.

Foray D., Morgan K., Radosevic S. (2018) The Role of Smart Specialisation in the EU Research and Innovation Policy Landscape, Brussels: European Commission. Available at: http://ec.europa.eu/regional_policy/sources/docgener/brochure/smart/role_smartspecialisation_ ri.pdf, accessed 13.01.2019.

Gheorghiu R., Andreescu L., Zulean M., Curaj A. (2017) Entrepreneurial Discovery as a Foresight for Smart Specialization: Trade-Offs of Inclusive and Evidence-Based Consensus. Advances in the Theory and Practice of Smart Specialization (eds. S. Radošević, A. Curaj, R. Gheorghiu, I. Wade), Amsterdam: Academic Press, pp. 319-344. Available at: https://doi.org/10.1016/B978-0-12-804137-6.00014-0, accessed 09.12.2018 
Haberleithner J., Demblans A., Gómez J., Palazuelos M. (2018) Smart Specialization Worldwide: Federative Republic of Brazil, Brussels: European Commission.

IBICT (2013) Brasilia 2060 - Structure Plan, Brasilia: Ministério da Ciência, Tecnologia e Inovação (MCTI). Available at: https://issuu.com/ assinter/docs/brasilia_2060, accessed 12.12.2018.

IBICT (2018) Descoberta Empreendedora: Especialização Inteligente para a Economia Criativa em Brasília [Entrepreneurial Discovery: Smart Specialization for the Creative Economy in Brasilia]. Socialismo Criativo, 18.06.2018. Available at: http://socialismocriativo.com.br/ descoberta-empreendedora-especializacao-inteligente-para-a-economia-criativa-em-brasilia/, accessed 02.03.2019.

Ingold R., Ovanessoff A., Plastino E. (2015) Outlook: Unleashing Brazil's Innovation Potential, Sao Paolo: Accenture. Available at: https://www. accenture.com/t20150521T071944Z w _ /us-en/_acnmedia/Accenture/Conversion-Assets/Outlook/Documents/2/Accenture-OutlookUnleashing-Brazil-Innovation-Potential.pdf\#zoom=50, accessed 01.03.2019.

JRC EC (n.d.) Smart Specialisation for lagging regions, Brussels: Joint Research Centre of the European Commission. Available at: https:// ec.europa.eu/jrc/sites/jrcsh/files/Smart\%20Specialisation\%20for\%20lagging\%20regions.pdf, accessed 22.12.2018.

Ketels C., Nauwelaers C., Cassingena-Harper J., Lindqvist G., Lubicka B., Peck F. (2013) The Role of Clusters in Smart Specialisation Strategies, Brussels: European Commission. Available at: https://ec.europa.eu/research/evaluations/pdf/archive/other_reports_studies_and_ documents/clusters_smart_spec2013.pdf, accessed 11.01.2019.

Kotnik P., Petrin T. (2017) Implementing a smart specialisation strategy: An evidence-based approach. International Review of Administrative Sciences, vol. 83, no 1, pp. 85-105. Available at: https://doi.org/10.1177/0020852315574994, accessed 15.01.2019.

Kroll H. (2014) Efforts to Implement Smart Specialization in Practice - Leading Unlike Horses to the Water. European Planning Studies, vol. 23, no 10, pp. 2079-2098. Available at: https://doi.org/10.1080/09654313.2014.1003036, accessed 22.12.2018.

Kuznetsov Y., Sabel C. (2017) Managing Self-Discovery: Diagnostic Monitoring of a Portfolio of Projects and Programs. Advances in the Theory and Practice of Smart Specialization (eds. S. Radošević, A. Curaj, R. Gheorghiu, I. Wade), Amsterdam: Academic Press, pp. 51-72. Available at: https://doi.org/10.1016/B978-0-12-804137-6.00003-6, accessed 21.12.2018.

Landabaso M., Foray D. (2014) From smart specialisation to smart specialisation policy. European Journal of Innovation Management, vol. 17, no 4, pp. 492-507. Available at: https://doi.org/10.1108/EJIM-09-2014-0096, accessed 02.03.2019.

Landabaso M., McCann P., Ortega-Argilés R. (2014) Smart specialisation in European regions: Issues of strategy, institutions and implementation. European Journal of Innovation Management, vol. 17, no 4, pp. 409-427. Available at: https://doi.org/10.1108/EJIM-05-2014-0052, accessed 02.03.2019.

Maragna L. (2016) RIO Country Report 2015: Brazil, Brussels: European Commission.

Marques P., Morgan K. (2018) The Heroic Assumptions of Smart Specialisation: A Sympathetic Critique of Regional Innovation Policy. New avenues for regional innovation systems: Theoretical advances, empirical cases and policy lessons (eds. A. Isaksen, R. Martin, M. Trippl), Cham, Switzerland: Springer.

Mazzucato M., Caetano P. (2016) The Brazilian Innovation System: A Mission-Oriented Policy Proposal, Brasília: CGEE.

McCann P., Ortega-Argilés R. (2013) Smart Specialization, Regional Growth and Applications to European Union Cohesion Policy. Regional Studies, vol. 49, no 8, pp. 1291-1302. Available at: https://doi.org/10.1080/00343404.2013.799769, accessed 22.12.2018.

McCann P., Ortega-Argilés R. (2016a) The early experience of smart specialization implementation in EU cohesion policy. European Planning Studies, vol. 24, no 8, pp. 1407-1427. Available at: https://doi.org/10.1080/09654313.2016.1166177, accessed 22.12.2018.

McCann P., Ortega-Argilés R. (2016b) Smart Specialisation: Insights from the EU Experience and Implications for Other Economies. Investigaciones Regionales - Journal of Regional Research, vol. 36, pp. 279-293.

MCTIC (2016) Estratégia Nacional De Ciência, Tecnologia E Inovação 2016-2022 [National Strategy for Science, Technology and Innovation], Brasília: Ministério da Ciência, Tecnologia, Inovações e Comunicações (MCTIC).

MCTIC (2018) Recursos Aplicados - Indicadores Consolidados [Applied Resources - Consolidated Indicators], Brasília: Ministério da Ciência, Tecnologia, Inovações e Comunicações (MCTIC). Available at: https://www.mctic.gov.br/mctic/opencms/indicadores/detalhe/recursos_ aplicados/indicadores_consolidados/2_1_3.html, accessed 02.03.2019.

MDIC (2018) Arnajos Produtivos Locais - APL, Brasília: Ministério da Indústria, Comércio Exterior e Serviços (MDIC). Available at: http:// www.mdic.gov.br/index.php/competitividade-industrial/arranjos-produtivos-locais, accessed 02.03.2019.

Negri F. (2018) Novos caminhos para a inovação no Brasil [New paths for innovation in Brazil], Washington, D.C.: Wilson Center.

OECD (2012) Economic Policy Reforms 2012: Going for Growth, Paris: OECD.

OECD (2013) Innovation-driven Growth in Regions: The Role of Smart Specialisation, Paris: OECD.

OECD (2014) OECD Science, Technology and Industry Outlook 2014, Paris: OECD.

Oliveira F., Ovanessoff A., Peppes A., Plastino E. (2014) Yesterday's Truths, Today's Realities: A New Global Mindset for Brazilian Business, Sao Paolo: Accenture. Available at: https://www.accenture.com/t20170411T175630Z_w__us-en/_acnmedia/Accenture/Conversion-Assets/ DotCom/Documents/Global/PDF/Digital_3/Accenture-Brazil-Yesterdays-Truths-Todays-realities-Zoom-Fixed.pdf\#zoom=50, accessed 22.12.2018.

Ovanessoff A., Peppes A. (2015) What Business Must Do to Reignite Brazil's Productivity, Sao Paolo: Accenture. Available at: https://www.accenture. com/t20170411T175826Z_w__/us-en/_acnmedia/PDF-32/Accenture-What-Business-Must-Do-To-Reignite-Brazil-Productivity-Growth. pdf\#zoom $=50$, accessed $22.12 . \overline{20} 18$.

Pinto H. (2018) RIS3-PE: Final Report: For a vision of the Smart Specialisation Strategy in selected innovative territories of the State of Pernambuco, Brussels: European Commission. Available at: https://ec.europa.eu/regional_policy/sources/cooperate/international/pdf/RIS3-PE_Final_ report_en.pdf, accessed 24.12.2018.

Radosevic S. (2017) Advancing Theory and Practice of Smart Specialization: Key Messages. Advances in the Theory and Practice of Smart Specialization (eds. S. Radošević, A. Curaj, R. Gheorghiu, I. Wade), Amsterdam: Academic Press, pp. 345-355. Available at: https://doi. org/10.1016/B978-0-12-804137-6.00015-2, accessed 22.12.2018.

Veldhuizen C., Wilson B., Coenen L., Goedegebuure L., Schoen M. (2018) State of the Art Review of Smart Specialisation in Europe, Melbourne: University of Melbourne. Available at: https://sustainable.unimelb.edu.au/_data/assets/pdf_file/0006/2792319/State-of-the-Art-Review-ofSmart-Specialisation-in-Europe.pdf, accessed 21.12.2018.

World Bank Group (2018) Doing Business 2018 - Reforming to Create Jobs, Washington, D.C.: World Bank Group. Available at: http://www. doingbusiness.org/content/dam/doingBusiness/media/Annual-Reports/English/DB2018-Full-Report.pdf, accessed 02.03.2019. 